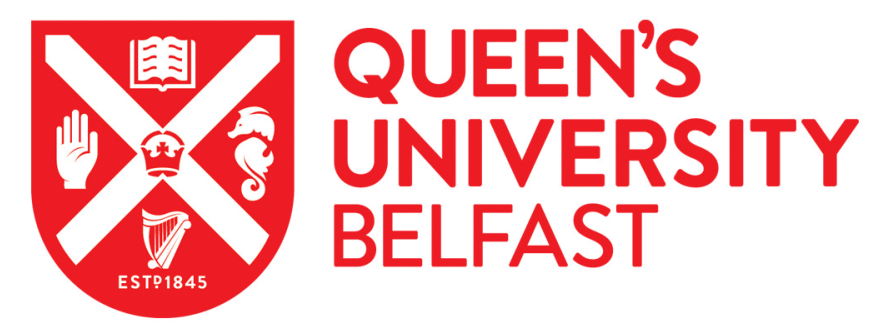

\title{
Novel use of soil moisture samplers for studies on anaerobic ammonium fluxes across lake sediment-water interfaces
}

Song, J., Luo, Y. M., Zhao, Q. G., \& Christie, P. (2003). Novel use of soil moisture samplers for studies on anaerobic ammonium fluxes across lake sediment-water interfaces. Chemosphere, 50(6), 711-715.

Published in:

Chemosphere

Queen's University Belfast - Research Portal:

Link to publication record in Queen's University Belfast Research Portal

\section{General rights}

Copyright for the publications made accessible via the Queen's University Belfast Research Portal is retained by the author(s) and / or other copyright owners and it is a condition of accessing these publications that users recognise and abide by the legal requirements associated with these rights.

Take down policy

The Research Portal is Queen's institutional repository that provides access to Queen's research output. Every effort has been made to ensure that content in the Research Portal does not infringe any person's rights, or applicable UK laws. If you discover content in the Research Portal that you believe breaches copyright or violates any law, please contact openaccess@qub.ac.uk. 


\title{
CHEMOSPHERE
}

\section{Novel use of soil moisture samplers for studies on anaerobic ammonium fluxes across lake sediment-water interfaces}

\author{
J. Song ${ }^{\text {a }}$, Y.M. Luo ${ }^{\mathrm{a}, *}$, Q.G. Zhao ${ }^{\mathrm{a}}$, P. Christie ${ }^{\mathrm{b}}$ \\ a Institute of Soil Science, Chinese Academy of Sciences, P.O. Box 821, Nanjing 210008, China \\ ${ }^{\mathrm{b}}$ Department of Agricultural and Environmental Science, Queen's University Belfast, Newforge Lane, Belfast BT9 5 PX, UK
}

\begin{abstract}
Small soil suction samplers have been used for several years to sample soil solution for chemical analysis in laboratory and glasshouse experiments. They are very cheap, effective and convenient. Here we describe for the first time their use in studies on sediment porewater. Bulk sediment from West Lake, a shallow hypereutrophic lake in Hangzhou, Zhejiang Province, China, was placed in laboratory microcosms and incubated in the dark at $25{ }^{\circ} \mathrm{C}$ for 182 days to evaluate the feasibility of using the samplers to extract sediment porewater and to estimate $\mathrm{NH}_{4}^{+}$flux across the sediment-water interface under anaerobic conditions. The results show that the samplers were capable of sequentially extracting sediment porewater, $15 \mathrm{ml}$ of which could be readily extracted for analysis within $30-45$ min by vacuum applied using a plastic syringe. The $\mathrm{NH}_{4}^{+}$flux under laboratory conditions was characterized by a fast phase during the initial 18 days of incubation followed by a slower linear phase, with average release rates of 11.6 and $3.6 \mathrm{mg} \mathrm{N} \mathrm{m}^{-2} \mathrm{~d}^{-1}$, respectively.
\end{abstract}

(C) 2002 Elsevier Science Ltd. All rights reserved.

Keywords: Diffusive flux; Porewater; Soil suction samplers; West Lake

\section{Introduction}

Nitrogen $(\mathrm{N})$ is one of the factors limiting algal growth in eutrophic waters. It is generally recognized that organic-rich sediments can act as important sources of $\mathrm{N}$ to the water column of shallow lakes, especially when external inputs are greatly reduced. In the past decade, $\mathrm{N}$ cycling has been documented in a variety of aquatic environments, including lake sediments (Carignan and Lean, 1991; D'Angelo and Reddy, 1993; Reddy et al., 1996; Van Luijn et al., 1999), marine and estuarine sediments (Kemp et al., 1990; Sumi and Koike,

\footnotetext{
${ }^{*}$ Corresponding author. Tel.: +86-25-322-8236; fax: +86-253353-590.

E-mail address: ymluo@issas.ac.cn (Y.M. Luo).
}

1990) and wetlands (D'Angelo and Reddy, 1994a,b; Zhu and Ehrenfeld, 1999).

Studies have shown that $\mathrm{NH}_{4}^{+}$regenerated during microbial decomposition of sediment organic matter can then be transported to the water column via diffusion, sediment resuspension, bioturbation and gas ebullition. The contribution of each path to $\mathrm{NH}_{4}^{+}$flux has varied significantly in different studies. Carignan and Lean (1991) reported that during summer anoxia, $70 \%$ of the hypolimnetic accumulation of $\mathrm{NH}_{4}^{+}$was accounted for by diffusion from the sediments of William Bay, Canada. In contrast, the results of Reddy et al. (1996) suggest that dissolved $\mathrm{NH}_{4}^{+}$transport from the surface $8 \mathrm{~cm}$ of sediment was due to sediment resuspension, and below this depth upward mobility of $\mathrm{NH}_{4}^{+}$was regulated by diffusion.

Data on $\mathrm{NH}_{4}^{+}$concentrations in porewater are needed to quantify the diffusive flux of $\mathrm{NH}_{4}^{+}$using Fick's 
first law. Generally, porewater sampling methods can be classified as non-destructive or destructive. For instance, porewater can be sampled in situ by passive equilibration with the close-interval sampler, first introduced by Hesslein (1976), and its modifications (Shaw and Prepas, 1989). More recently, a practical device that allows simultaneous and sequential sampling of porewater at different depths at the same location was described by Ugo et al. (1999). In addition, porewater can be extracted by means of destructive methods such as pressure filtration, centrifugation and anaerobic centrifugation. The last two methods are commonly adopted in laboratory studies. A review comparing the advantages and disadvantages of various soil solution sampling techniques has been recently published by Song et al. (2000).

The 'Rhizon SMS' soil moisture sampler (Rhizosphere Research Products, Doderstraat 62, 6706 JG Wageningen, The Netherlands) is a small, simple and easy-to-use device capable of sequential extraction of soil solution in situ ( $\mathrm{Wu}$ and Luo, 1999). Due to its simplicity in installation and high temporal and spatial resolution, the suction sampler has been widely used to study chemical processes that occur in soil zones such as the rhizosphere. However, to our knowledge, no attempt has ever been made to extract sediment porewater using this type of sampling device.

The objectives of this study were to evaluate the feasibility of using small soil moisture samplers to extract sediment porewater and to determine the rate of $\mathrm{NH}_{4}^{+}$release from lake sediments during anaerobic incubation.

\section{Materials and methods}

\subsection{Study site and sampling}

The samplers were evaluated using sediment samples collected from West Lake, a shallow hypereutrophic lake located in Hangzhou city, East China. The lake has a surface area of $5.66 \mathrm{~km}^{2}$ and an average depth of 1.56 $\mathrm{m}$. Factors such as the small storage capacity, insufficient water supply and long hydraulic retention time, and especially the excessive nutrient inputs from human activities in the past few decades have contributed to the hypereutrophic conditions in West Lake. Studies have shown that the surface sediments are characterized by high organic carbon content (average $129 \mathrm{~g} \mathrm{~kg}^{-1}$, maximum $219.6 \mathrm{~g} \mathrm{~kg}^{-1}$ ) and rather high $\mathrm{N}$ content (average $1.01 \mathrm{~g} \mathrm{~kg}^{-1}$, maximum $1.55 \mathrm{~g} \mathrm{~kg}^{-1}$ ) (Wu et al., 1990). Bulk sediments were collected on 18 October 1999 from the flocculent layer $(0-30 \mathrm{~cm})$ near the centre of West Lake. Subsurface water samples were also collected from the same location.

\subsection{Batch incubation experiment}

A batch incubation experiment was conducted in quadruplicate using cylindrical polythene containers. A small hole was drilled on the sidewall $0.5 \mathrm{~cm}$ above the base of the container, and a soil suction sampler was inserted through a rubber stopper to the centre of the container. Thoroughly homogenized wet sediment (1675 $\mathrm{g}$, equivalent to $201 \mathrm{~g}$ dry sediment) was placed into a $3454 \mathrm{ml}$ container and then $1250 \mathrm{ml}$ of filtered West Lake water was carefully added. The containers were sealed with rubber stoppers that held a redox $(\mathrm{Pt})$ electrode, an $\mathrm{Ag}-\mathrm{AgCl}$ electrode, a compound $\mathrm{pH}$ electrode and a thermometer (Fig. 1). The Pt electrode and the compound $\mathrm{pH}$ electrode were carefully placed so that their sensors could be inserted about $1 \mathrm{~cm}$ into the sediments when the containers were plugged with the rubber stoppers. After the headspace was replaced with $99.999 \%$ pure $\mathrm{N}_{2}$, the container was sealed with silicone glass cement and then incubated in the dark at $25^{\circ} \mathrm{C}$. The $\mathrm{pH}$ and $\mathrm{Eh}$ of the sediments were monitored regularly, and the Eh measurements were converted to pe values using the Nernst equation. On days $0,28,39,53$, $63,78,91,104,127,147,167$ and $182,15 \mathrm{ml}$ of porewater was extracted using a plastic syringe connected to the suction sampler. The airtight containers were then uncovered and $75 \mathrm{ml}$ of overlying water was withdrawn using a large syringe. The $90 \mathrm{ml}$ of water removed was replenished with fresh West Lake water after filtration through ashless filter paper, and the headspace was purged with $99.999 \%$ pure $\mathrm{N}_{2}$. The containers were then sealed and incubated in the dark at $25^{\circ} \mathrm{C}$ until the subsequent sampling time.

Overlying water samples were filtered through 0.45 $\mu \mathrm{m}$ pore size membrane filters before analysis for $\mathrm{NH}_{4}^{+}$ using Nesslerization. The $\mathrm{NH}_{4}^{+}$concentrations in the porewater samples were determined directly using the same method.

Cumulative $\mathrm{NH}_{4}^{+}$fluxes across the sediment-water interface were calculated from the equation given by Jin and $\mathrm{Tu}$ (1990) and diffusive fluxes of $\mathrm{NH}_{4}^{+}$were estimated using Fick's first law. The results are presented as the mean values of four replicate samples.

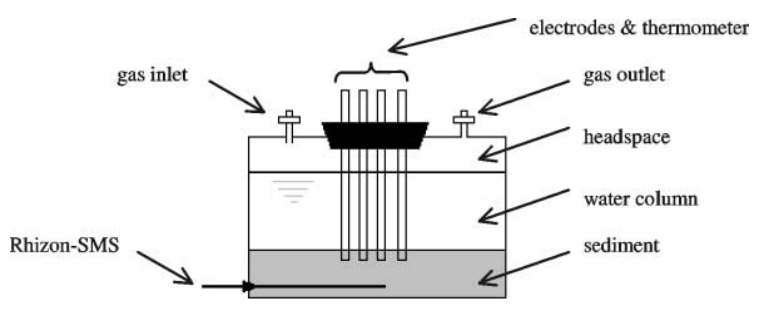

Fig. 1. Schematic diagram of the experimental setup used in the laboratory study. 


\section{Results}

\subsection{The pe and $p H$ dynamics in the sediment}

During the first 10 days of incubation, sediment $\mathrm{pH}$ decreased from 7.16 on day 0 to 6.87 on day 10 . Thereafter, sediment $\mathrm{pH}$ was almost stable at around $6.86 \pm 0.02$ until day 109 , when the $\mathrm{pH}$ began to decline and finally stabilized at $6.79 \pm 0.02$ from day 117 (Fig. 2). Sediment pe value dropped sharply from -3.1 on day 0 to -7.6 on day 8 . Then it began to rise and reached -6.4 on day 31 . The sediment pe subsequently decreased slowly to -7.1 (Fig. 2).

The pe and $\mathrm{pH}$ data indicate that the sediment was under nearly neutral and highly reduced conditions throughout laboratory incubation. Under such conditions, $\mathrm{NH}_{4}^{+}$would be the dominant $\mathrm{N}$ species and $\mathrm{CH}_{4}$ production would be expected to occur.

\subsection{Porewater sampling}

At selected sampling dates, a plastic syringe was connected to the PVC tube of the suction sampler. About $30-45 \mathrm{~min}$ were required to extract $15 \mathrm{ml}$ of sediment porewater by vacuum applied using a syringe. As the solution passed through the porous polyester tube of the sampler with average pore size of $0.1 \mu \mathrm{m}(\mathrm{Wu}$ and Luo, 1999), the porewater that collected in the syringe was clear and ready for analysis. This avoided the possible exposure of the porewater sample to air with consequent changes in chemical composition. Extraction of porewater with the suction sampler was also less laborious than methods involving filtration and centrifugation. The most important advantages of the suction samplers were their convenience and their capacity to extract sediment porewater in situ, both non-destructively and sequentially.

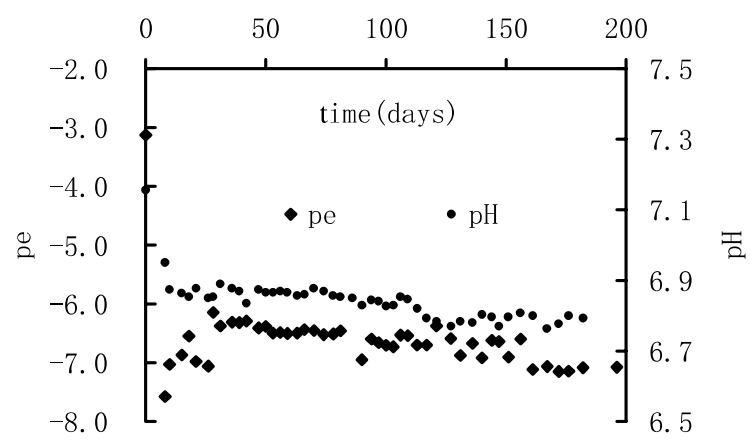

Fig. 2. Sediment pe and $\mathrm{pH}$ dynamics during anaerobic incubation.

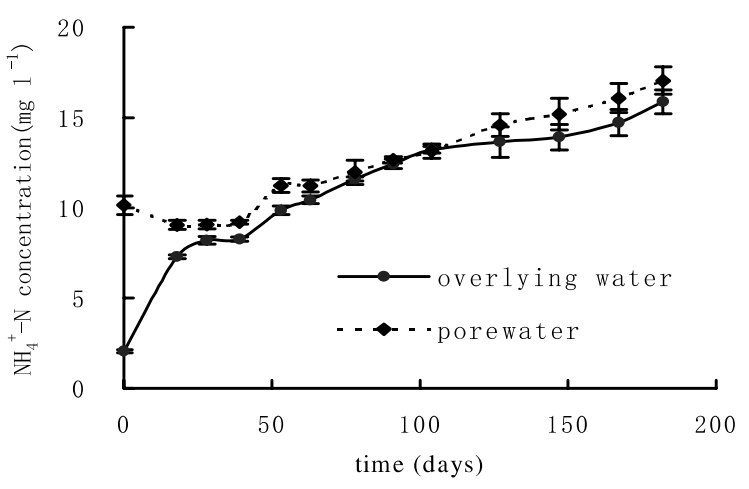

Fig. 3. $\mathrm{NH}_{4}^{+}$concentrations in overlying water and porewater during incubation. Bars: standard errors.

\section{3. $\mathrm{NH}_{4}^{+}$concentrations in overlying water and porewater}

$\mathrm{NH}_{4}^{+}$produced during anaerobic decomposition of sediment organic matter could be (1) adsorbed and fixed by fine particles such as clay minerals and referred to as exchangeable $\mathrm{NH}_{4}^{+}$, (2) released into the porewater to maintain the balance between exchangeable $\mathrm{NH}_{4}^{+}$and $\mathrm{NH}_{4}^{+}$concentration in the porewater, (3) assimilated into organic $\mathrm{N}$ by microorganisms, and (4) transported to overlying water by means of diffusion or sediment resuspension. In the absence of nitrification and coupled denitrification, $\mathrm{NH}_{4}^{+}$would accumulate in the water column.

As shown in Fig. 3, the $\mathrm{NH}_{4}^{+}$concentration in the overlying water showed a two-stage pattern. In the initial 18 days of incubation, the $\mathrm{NH}_{4}^{+}$concentration increased from $2.05 \mathrm{mgl}^{-1}$ on day 0 to $7.29 \mathrm{mgl}^{-1}$ on day 18. Correspondingly, the $\mathrm{NH}_{4}^{+}$concentration in the pore water dropped from $10.15 \mathrm{mgl}^{-1}$ to $9.05 \mathrm{mgl}^{-1}$. Thereafter, the differences between $\mathrm{NH}_{4}^{+}$concentrations in the overlying water and the porewater were much smaller. The overlying water appeared to have reached equilibrium with the porewater with respect to $\mathrm{NH}_{4}^{+}-\mathrm{N}$. However, a $t$-test indicated that no significant difference at the $p<0.05$ level occurred between $\mathrm{NH}_{4}^{+}$concentrations in overlying water and porewater from day 63 to day 104 .

\section{Discussion}

During the initial 18 days of incubation, the increase in overlying water $\mathrm{NH}_{4}^{+}-\mathrm{N}$ concentration was accompanied by a decrease in porewater $\mathrm{NH}_{4}^{+}-\mathrm{N}$ concentration. The increase in overlying water $\mathrm{NH}_{4}^{+}$concentration may have been due to diffusive flux of $\mathrm{NH}_{4}^{+}$from the sediment. To test this assumption, the diffusive flux of $\mathrm{NH}_{4}^{+}$was calculated from the porewater profiles using Fick's first law: 
$J=-\phi D_{\mathrm{s}}(\mathrm{d} C / \mathrm{d} x)$

where $J=$ diffusive flux of $\mathrm{NH}_{4}^{+}$in mass per unit area per unit time; $\phi=$ porosity (volume of water/unit volume of sediment); $D_{\mathrm{s}}=$ whole-sediment diffusion coefficient in terms of area per unit time; and $\mathrm{d} C / \mathrm{d} x=$ concentration gradient at sediment-water interface. According to the method of Song (1997), $D_{\mathrm{s}}$ was calculated as follows:

$D_{\mathrm{s}}=\phi^{2} D_{0}$

where $D_{0}=$ the ideal diffusion coefficient of $\mathrm{NH}_{4}^{+}$in infinitely diluted solution, and $\mathrm{d} C / \mathrm{d} x$ can be roughly replaced with $\Delta C / \Delta x$, the concentration difference near the sediment-water interface. $\mathrm{As}^{-} \mathrm{NH}_{4}^{+}$concentrations in overlying water and porewater were always changing, for simplicity we assumed that the concentrations changed linearly. The value for $D_{0}$ was taken from Song (1997) to be 19.8 in units of $10^{-6} \mathrm{~cm}^{2} \mathrm{~s}^{-1}$. The value for $\phi$ was determined in this study to be 0.88 . On the assumption of linearity stated above and the experimental data, the calculated average $\mathrm{NH}_{4}^{+}$flux during the first 18 days was $10.93 \mathrm{mg} \mathrm{N} \mathrm{m}^{2} \mathrm{~d}^{-1}$. This value was very close to the flux value calculated based on the changes in overlying water $\mathrm{NH}_{4}^{+}$concentration $\left(11.64 \mathrm{mg} \mathrm{N} \mathrm{m}^{2} \mathrm{~d}^{-1}\right)$. The close correspondence of these two methods of calculation confirms that diffusion was the dominant process in the first 18 days of incubation.

Similarly, diffusive fluxes for other periods were calculated. However, significant differences were found between the measured flux and the diffusive flux calculated using Fick's first law (data not shown). In most cases, the calculated fluxes were much smaller than the measured fluxes. The difference between measured and diffusive flux may be caused by (1) $\mathrm{NH}_{4}^{+}$released directly from the sediment-water interface, and (2) $\mathrm{NH}_{4}^{+}$transported to the water column via $\mathrm{CH}_{4}$ ebullition, which is very likely to occur under strongly reducing conditions.

Based on the overlying water data presented in Fig. 3 , the cumulative $\mathrm{NH}_{4}^{+}$flux across the sediment-water interface could be calculated. The trend in cumulative

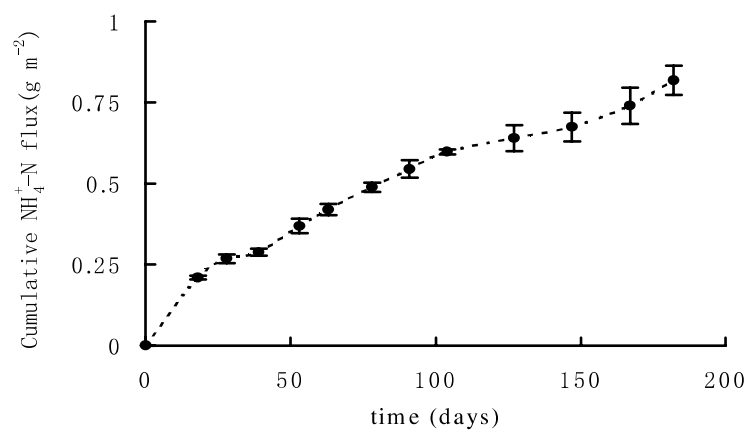

Fig. 4. Cumulative $\mathrm{NH}_{4}^{+}$flux across the sediment-water interface. Bars: standard errors.
$\mathrm{NH}_{4}^{+}$flux was similar to that observed for overlying water $\mathrm{NH}_{4}^{+}$concentration (Fig. 4). A fast increase in $\mathrm{NH}_{4}^{+}$flux between days 0 and 18 was followed by a steady increase at a slower rate. A linear regression was calculated for the data of the slow phase. The average release rates were $11.64 \mathrm{mg} \mathrm{N} \mathrm{m}^{2} \mathrm{~d}^{-1}$ for the fast phase and $3.6 \mathrm{mg} \mathrm{N} \mathrm{m}^{2} \mathrm{~d}^{-1}\left(R^{2}=0.9776\right)$ for the subsequent slower phase.

\section{Conclusions}

This study has demonstrated that 'Rhizon' SMS samplers can be used to extract sediment porewater in laboratory studies. They are convenient devices for use in microcosm experiments and permit repeated sampling with minimal disturbance of the experimental system. In our study, the $\mathrm{NH}_{4}^{+}$release was characterized by a fast phase followed by a linear slower phase. Diffusion was found to be the dominant process in the initial fast phase of $\mathrm{NH}_{4}^{+}$release.

\section{Acknowledgements}

The authors are grateful for grant-aided support from the National Science Foundation of China (no. 49831070 and no. 40125005) and from the Major State Basic Research and Development Program of the People's Republic of China (G1999011807). This study was also supported by the Laboratory of Material Cycling in Pedosphere (LMCP) and the Joint Open Laboratory of Soil and Environment (JOLSE), both at the Institute of Soil Science, Chinese Academy of Sciences.

\section{References}

Carignan, R., Lean, R.S., 1991. Regeneration of dissolved substances in a seasonally anoxic lake: the relative importance of processes occurring in the water column and in the sediments. Limnol. Oceanogr. 36 (4), 683-707.

D’Angelo, E.M., Reddy, K.R., 1993. Ammonium oxidation and nitrate reduction in sediments of a hypereutrophic lake. Soil Sci. Soc. Am. J. 57 (4), 1156-1163.

D’Angelo, E.M., Reddy, K.R., 1994a. Diagenesis of organic matter in a wetland receiving hypereutrophic lake water: I. Distribution of dissolved nutrients in the soil and water column. J. Environ. Qual. 23 (5), 928-936.

D’Angelo, E.M., Reddy, K.R., 1994b. Diagenesis of organic matter in a wetland receiving hypereutrophic lake water: II. Role of inorganic electron acceptors in nutrient release. J. Environ. Qual. 23 (5), 937-943.

Hesslein, R.H., 1976. An in situ sampler for close interval pore water studies. Limnol. Oceanogr. 21 (6), 912-914.

Jin, X.C., Tu, Q.Y., 1990. In: Regulations for Lake Eutrophication Investigation, second ed. China Environmental Science Press, Beijing, 231pp. (in Chinese). 
Kemp, W.M., Sampou, P., Caffrey, J., Mayer, M., Henriksen, K., Boynton, W.R., 1990. Ammonium recycling versus denitrification in Chesapeake Bay sediments. Limnol. Oceanogr. 35 (7), 1545-1563.

Reddy, K.R., Fisher, M.M., Ivanoff, D., 1996. Resuspension and diffusive flux of nitrogen and phosphorus in a hypereutrophic lake. J. Environ. Qual. 25 (2), 363-371.

Shaw, J.F.H., Prepas, E.E., 1989. Temporal and spatial patterns of porewater phosphorus in shallow sediments, and its potential transport into Narrow Lake, Alberta. Can. J. Fish. Aquat. Sci. 46 (6), 981-988.

Song, J., Luo, Y.M., Zhao, Q.G., 2000. Progress in study of soil solution techniques. Soils 32, 102-106 (in Chinese).

Song, J.M., 1997. In: Chemistry of Sediment-Seawater Interface of the China Seas. China Ocean Press, Beijing, p. 6 (in Chinese).

Sumi, T., Koike, I., 1990. Estimation of ammonification and ammonium assimilation in surficial coastal estuarine sediments. Limnol. Oceanogr. 35 (2), 270-285.
Ugo, P., Bertolin, A., Moretto, L.M., 1999. Monitoring sulphur species and metal ions in salt-marsh pore-waters by using an in-situ sampler. Int. J. Environ. Anal. Chem. 73 (2), 129143.

Van Luijn, F., Boers, P.C.M., Lijklema, L., Sweerts, J.-P.R.A., 1999. Nitrogen fluxes and processes in sandy and muddy sediments from a shallow eutrophic lake. Water Res. 33 (1), 33-42.

Wu, J.B., Jiao, L., Zhang, Y.C., 1990. The surficial sediments at the bottom of West Lake, Hangzhou-The accumulation and feedback of inner load. In: Xu, Y.H. et al. (Eds.), 4th International Conference on the Conservation and Management of Lakes, Hangzhou. Anthology of Research on West Lake's Environment, pp. 91-99 (in Chinese).

Wu, L.H., Luo, Y.M., 1999. Rhizon-soil moisture sampler-an introduction to an innovative in situ soil solution sampler. Soils 31, 54-56 (in Chinese).

Zhu, W.X., Ehrenfeld, J.G., 1999. Nitrogen mineralization and nitrification in suburban and undeveloped Atlantic white cedar wetlands. J. Environ. Qual. 28 (2), 523-529. 